\title{
Nexus between Product Innovation and Enterprise Survival: Impact of Competitive Intensity and Competitive Advantage
}

Lin Lu Zhou ${ }^{1}$, James Onuche Ayegba ${ }^{1,4 *}$, Peace Maina James ${ }^{2}$ Emmanuel Onu Ayegba $^{3}$, Zhang Xin jie ${ }^{1}$, Arielle Doris Tetgoum Kachie ${ }^{1}$

1. School of Management Science and Engineering, Department of Marketing, Jiangsu University, Jiangsu, 212013, China; 5103150216@stmail.ujs.edu.cn; zl162@126.com; zhangxinjie1218@126.com; doriskachie2020@outlook.com

2. Department of Accounting, Nasarawa State University, Keffi, 960169, Nigeria; peacemainajames@gmail.com

3. Department of Business Strategy and Planning, Nigerian National Petroleum Corporation, 900271, Nigeria; emmanuelonuayegba@outlook.com

4. Department of Business Administration, Faculty of Administration, Ahmadu Bello University, (Kongo Campus), 810222 Zaria, Nigeria

*Correspondence: 5103150216@stmail.ujs.edu.cn

\begin{abstract}
Product innovation is a crucial factor in enterprise survival. Even though there are sources from strategic theory that guides the clear comprehension towards appreciating the nexus between these two variables (product innovation and enterprise survival), there are still many lacunas that should be addressed and filled. Consequently, the need for additional empirical corroboration or support is pertinent. This study aimed at verifying the nexus between product innovation and enterprise survival, and how they are affected by the existence of antecedent variables such as competitive intensity and competitive advantage. In the methodology, this study adopts the conduct of explanatory and cross-sectional investigations through the use of structural equation modelling (SEM) to a sample of selected food and beverages enterprises in Lagos, Nigeria. Regarding the food and beverage enterprises in Lagos, Nigeria, this study discovered that competitive intensity has huge positive implication on product innovation at $(0.39 ; \mathrm{t}=5.69, \mathrm{p}<0.05)$. This gives numerical evidence that, in the face of more market competition, enterprises will be pressured to adopt the model of costs reduction on products which will enhance the reduction of product prices, and will have significant impact on profit. However, the findings reveal that there is no significance between competitive advantage and product
\end{abstract}


innovation at $(0.002 ; \mathrm{t}=0.203, \mathrm{p}>0.05)$, and there is no significance between product innovation and enterprise survival at $(-0.035 ; \mathrm{t}=-1.583, \mathrm{p}>.05)$. As a result, the food and beverage enterprises should concentrate more on product innovation so that they will be able to stand the intensity of competition. The results emanated from the study is germane as it make significant contribution to literature and the body of knowledge and on strategic management by enlightening that competitive intensity is a necessary inducement for product innovation.

Keywords: Product innovation; enterprise survival; competitive intensity; competitive advantage

\subsection{INTRODUCTION}

Studies of Rosenbusch, Brinckmann, and Bausch [1]; Marín-Idárraga, Hurtado, and Cabello [2] have shown that product innovation is a value-addition activity for enterprises, and Keupp, Palmié, and Gassmann [3] noted that it has been an approach for realizing competitive advantage. Though some in some studies, it was theoretically revealed that product innovation is a factor that determine enterprise survival [4],[5],[6]. Rosenbusch et al. [1] noted that empirical results of many studies are contradictory, especially those that treated small and medium-sized enterprises (SMEs). Some empirical researches reveal a positive and significant nexus between product innovation and enterprise survival [6],[7], while other researches reveals negative nexus [8],[9]. From the result obtained in various studies, there were suggestions that other factors may be affecting the nexus between product innovation and enterprise survival. In view of this, there is thus a need to embark on the study based on selected food and beverages enterprises in Lagos, Nigeria.Furthermore, many studies have been carried out and have analyzed the antecedent variables that affect the nexus between product innovation and enterprise survival. Among are the studies of Vermeulen, De Jong, and O'shaughnessy [10]; Chang, Hughes, and Hotho [11]; Alegre and Chiva [7], but there are some gaps to be filled because of country specific studies which open a prospect to observe the different variables that have suspect of influencing this nexus. To embark on this, this study determines whether competitive intensity and competitive advantage has influence on product innovation, which will result to improving enterprise survival. This study is therefore rooted on the following questions: 


\section{What is the nexus between product innovation and enterprise survival as affected by the antecedent variables of competitive intensity and competitive advantage?}

The two variables were selected based on their significance, relevance and effects on the survival of the enterprise. As a matter of fact, this nature or dynamic of study may not have been studied in Nigeria and for the large scale enterprises. Competitive intensity is best identified or known as the nature of contention that an enterprise encounters. It is one of the major threats to an enterprise most especially the younger or newer enterprises and a crucial market determinant affecting enterprise survival, it have greater influence on whether an enterprise will go into the unforeseeable future or not, it also have greater influence on how the enterprise will sustain the present economic hardship experienced in the country [12],[13]. If not properly examined, most enterprise will become comatose during the hard or unfavourable government policy

Enterprise survival is the act of sustaining an enterprise under a harsh, severe, or an unusual situation. It is usually inevitable when an enterprise failed to fulfil the mandate, especially during hard-hitting circumstances such as global and national economic recession. According to Adeniran and Ben [14], the period of recession is usually evidenced by a drop in the following economic indices: Real Gross Domestic Product (GDP); Income level of individual and revenue generation of government; Employment; Manufacturing; and Retail sales. It is usually better for a company to maintain good standing of survival [15]. The theoretical underpinning was empirically validated using a sample of selected food and beverages enterprises in Lagos, Nigeria. This sample of enterprise is particularly significant because food and beverage industry has huge impact on the viability of the economy.

An explanatory research was achieved through cross-sectional investigation and analyzed with structural equation model (SEM). The result reveals that, in the situation of tensed competitive intensity, enterprises looks for survival measures such as product innovation strategies, which enhances enterprise survival. Because the study analyzes competitive intensity and 
competitive advantage as antecedent variables of product innovation resulting to enterprise survival which may not been studied earlier, therefore, this study is innovative in nature.

\subsection{LITERATURE REVIEW}

The nomenclature of innovation is rooted around technology and administration. Technological innovation can be likened to process or product innovation, it is mainly associated with organization's tangible activity. While administrative innovation can be likened to management practices and organizational structure, It has forms the intangible aspect and most limited to the managerial practices [4]. The management of product innovation is a functional aspect in the survival of any enterprise [16]. A very good approach to manage product innovation is to determine whatever will hinder the survival of the enterprise holistically through critical examination of enterprise operations using Research and Development strategy [17].

Product innovation according to Drucker [18]; Wolfe [19]; Damanpour [20]; Damanpour and Gopalakrishnan [21]; Damanpour and Wischnevsky [22]; Gopalakrishnan, Kessler, and Scillitoe [23] is an activity that is considered as the core strategic inducement and a crucial element of sustainability. It is also a spring of competitive advantage. Van de Ven [24] out that product innovation is concerned with the formulation and implementation of new product ideas over time. They observed that product innovation result to exploring new opportunities and gaining more strength.

The top and middle managers of enterprises particularly the large scale enterprises make certain decisions about the structure and design of the enterprise such that it will be able to thrive in the complex and unpredictable business environment. They get to support the organizational structure, organizational culture, and business strategy thereby contributing significantly to value creation and competitive advantage in the face of environmental forces that seems to threaten the survival of the enterprise [25],[6],[26].

Keupp et al. [3] observed that in the light of environmental factors, enterprises must come up with endogenous factors that facilitate coping in the face of intense market competition, where product innovation is seen as a major resource to realizing competitive advantages. Study of Wang [27] reveals that product innovation is a basis for dynamic capabilities that can enhance enterprise survival over time. The importance of product innovation as a main 
factor is emphasized in this study, most especially during competition. Figure 1 show the conceptual model adopted in the research.

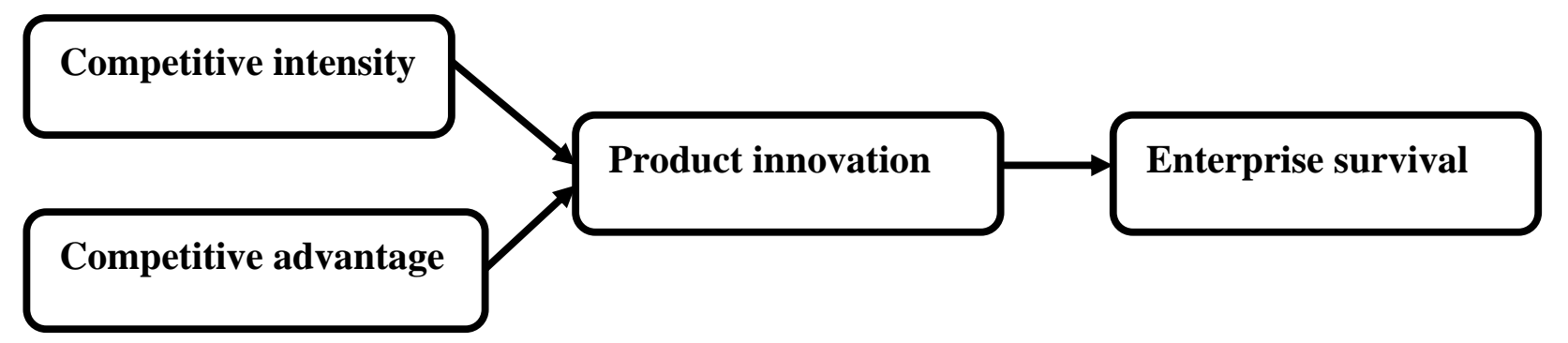

Figure 1: Conceptual model of the study

Source: Author (2020)

\section{MATERIALS AND METHODOLOGY}

This research is an explanatory and cross-sectional study, and it is achieved with SEM to validate the model specified. The SEM is preferred because it explains the nexus between numerous independent variables and singular dependent variable that, sequentially, becomes independent for another dependent variable [28] as presented in Figure 1. This similar design was been adopted in the studies of Ziolkowska [29]. Frankfort-Nachmias and Nachmias [30] noted that the survey design enhances better possibilities of unfolding existing phenomenon, situations and dynamics by which primary data are collected. It will enable the researcher to seek out the opinions of individual so as to reveal answers to or justify pertinent and specific questions that are comprehensive in the questionnaire instrument concerning the topic under consideration.

In the year 2014, the Nigerian Stock Exchange (NSE) [31] listed fourteen companies which comprises of multinational and indigenous companies. The population adopted in this study will comprise the categories of staff in the top and middle management cadre of the six (6) selected quoted food and beverages companies located in Lagos State. Six quoted food and beverages companies will be purposively selected (non probability sampling) for the study as they are noted to be major players and stakeholders in the Food and Beverages industry in Nigeria [32],[33]. From previous studies, it was revealed that the other eight companies were difficult to educing information from them.

According to Zikmund [34], the various error allowances will be determined and the suitable one will be chosen based on the discretion of the researcher. The chosen error 
allowance of 0.04 will be employed to establish the sample size as shown in the equation below:

The formulae for achieving sample size $n=\frac{Z^{2}}{4 E^{2}}$

where;

$\mathrm{n}=$ Sample size;

$\mathrm{Z}=\mathrm{Z}$ score for the confidence interval (2.05);

$\mathrm{E}=$ Error allowance (0.04)

When inserted into the formula, Sample Size will be 656.6406, and approximately 657. It is therefore crucial that the questionnaire distribution will target six hundred and fifty seven respondents whom are middle and top managers in the six food and beverage manufacturing companies.

Structural Equation Modelling (SEM) of Partial Least Square (PLS) was adopted to determine the relationship that exists between competitive advantage, product innovation, and performance of food and beverage enterprises.

Structural equation modelling (SEM) is a multivariate statistical framework that is used to model complex relationships between directly and indirectly observed (latent) variables. It is a general framework which simultaneously solves the systems of linear equations and encompasses other techniques through the incorporation and integration of regression, factor analysis, path analysis, and latent growth curve modelling [35],[36]. SEM is used to estimate a system of linear equations to test the fit of a hypothesized "causal" model.

The first step in SEM deals with the visualization of "path diagram" or hypothesized model which is usually based on prior knowledge of established theories. In path diagrams, rectangles typically represent observed or directly measured variables, and circles or ovals typically represent unobserved or latent constructs which are defined by measured variables. Unidirectional arrows represent causal paths, where one variable influences another directly, and double-headed arrows represent correlations between variables. As shown in the studies of McDonald and Ho [37]; Pearl [38], the term "arc" was preferred than "causal path".

Figure 2 illustrates an example SEM model. The system of equations can be written as a number of separate equations or with a general matrix notation. 


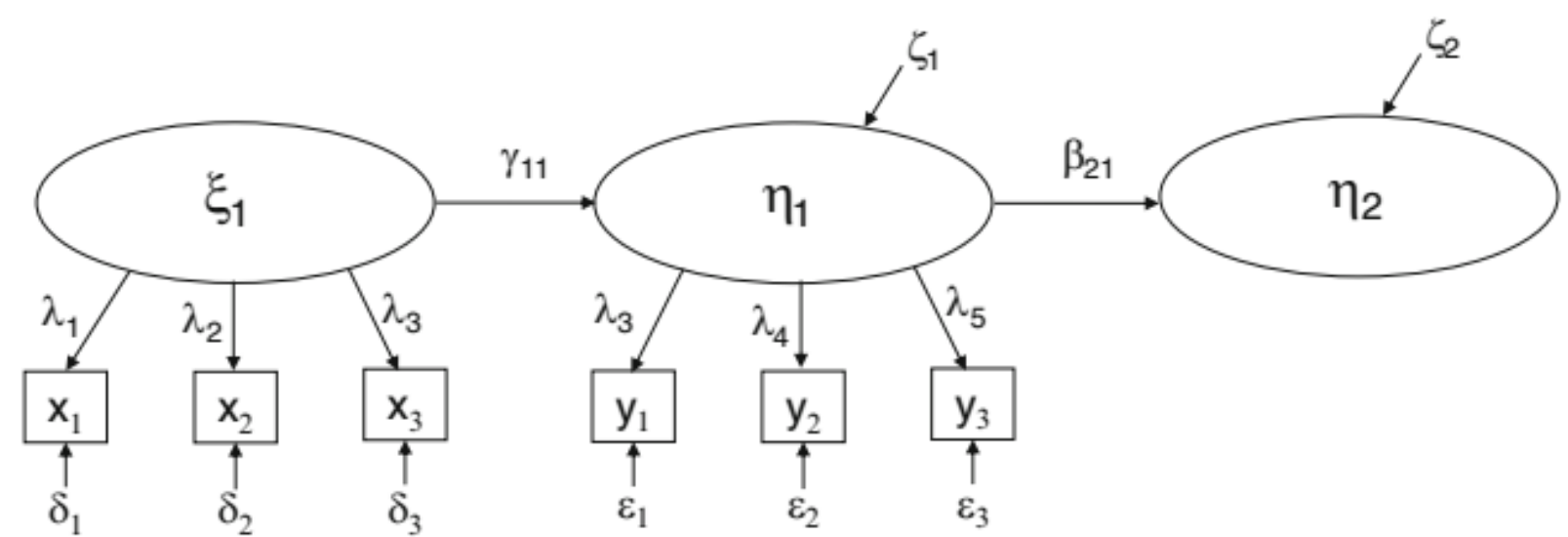

Figure 2: Example of SEM model

Source: Catherine, Nathan, and Nora [36]

SEMs comprises of two sub-models, they are:

1) The measurement model estimates relationships between the observed variables, also referred to as indicator variables, and latent variables; this is the same framework used in factor analysis. In regression and other statistical theories, "indicator variable" implies a binary yes/no sort of variable. Here, as is customary for SEM, "indicator variable" refers to a variable that is directly associated with a latent variable such that differences in the values of the latent variable mirror differences in the value of the indicator [39].

2) The structural model develops the relationships between the latent variables. For clarity of presentation, the system of equations will be described. The measurement model consists of the following equations, using standard notation used by Bollen [35]:

$$
\begin{array}{ll}
\mathrm{x}_{1}=\lambda_{1} \zeta_{1}+\delta_{1} & \mathrm{y}_{1}=\lambda_{3} \eta_{1}+\varepsilon_{1} \\
\mathrm{x}_{2}=\lambda_{2} \zeta_{2}+\delta_{2} & \mathrm{y}_{2}=\lambda_{4} \eta_{1}+\varepsilon_{2} \\
\mathrm{x}_{3}=\lambda_{3} \zeta_{3}+\delta_{3} & \mathrm{y}_{3}=\lambda_{5} \eta_{1}+\varepsilon_{3}
\end{array}
$$

Where the $\mathrm{x}^{\text {'s }}$ and $\mathrm{y}^{\prime \mathrm{s}}$ are observed indicators for latent variables, $\zeta{ }^{\prime s}$ and $\eta$ 's are latent variables, the $\lambda$ 's are the factor loadings, and $\varepsilon^{\prime s}$ and $\delta{ }^{\prime s}$ are the errors or disturbance terms. In general matrix notation, the measurement model is written as $\mathbf{x}=\Lambda_{\mathrm{x}} \zeta+\delta$ 
$\mathbf{y}=\Lambda_{\mathrm{y}} \eta+\varepsilon$

From the path diagram, the arrows point to the $\mathrm{x}^{\text {, }}$ and $\mathrm{y}$ 's, so they are modelled as dependent variables. Also, the factor loadings for $\mathrm{x}_{1}$ and $\mathrm{y}_{1}$ can be set to 1 , which can be done for two reasons:

i. The model is identifiable; and

ii. The latent variable is on the same statistical scale as the observed variables.

Model identification for SEM can also be achieved in other ways, such as setting the variance for the latent variable to 1 . Generally, the indicator with factor loading set to 1 is chosen based on

what the analyst deems is the best descriptor of the latent construct, but can be arbitrary. Finally in respect to model specification for SEM, exogenous variables have been differentiated from endogenous variables. Exogenous variables have no directed arcs ending on them, while endogenous variables have at least 1 arc ending on them. The structural model consists of the following equations:

$\eta_{1}=\gamma_{11} \xi_{1}+\zeta_{1}$

$\eta_{2}=\beta_{21} \xi_{2}+\zeta_{2}$

where the $\gamma$ and $\beta$ terms are factor loadings for the latent variables and $\zeta^{\prime s}$ are error terms. Here, the causal relationships between unobserved variables can be evaluated. In general, the structural model may be rewritten in matrix form as the following:

$\eta=\alpha+\mathbf{B} \eta+\Gamma \xi+\zeta$

where $\boldsymbol{\eta}$ is $m * 1$ vector of latent endogenous variables, $\xi$ is an $n * 1$ vector of latent exogenous variables, $\boldsymbol{\alpha}$ is an $n * 1$ vector of intercept terms, $\mathbf{B}$ is an $m * m$ matrix of coefficients that give the influence of $\boldsymbol{\eta}$ on each other, $\boldsymbol{\Gamma}$ is an $m * n$ matrix of the coefficients of the effect of $\xi$ on $\boldsymbol{\eta}$, and $\zeta$ is $m * 1$ vector of disturbances that contain the explained parts of the $\mathbf{\eta}$ 's. Though it may appear counter intuitive to regress on $\mathbf{\eta}$ on itself, each variable in $\mathbf{\eta}_{\mathbf{i}}$ is influenced by other variables in $\mathbf{\eta}_{\mathbf{i}}$, so this represents relationships between latent variables and not necessarily feedback loops. It was assumed that $\varepsilon, \delta$, and $\zeta$ are mutually uncorrelated.

Conventional regression approaches are robust to measurement errors in the outcome but not in the predictors. Also, univariate regression approaches cannot model the correlation between error terms for two different outcomes. SEM allows model measurement error for 
both the predictor and the outcome, and it allows a high degree of flexibility in modelling the correlation between the various error terms. In this study, the indicators were the constructs of dynamic capacities and enterprise performance, the analyst could model the correlation between one construct separately from another construct. Also, the SEM allows for the decomposition of effects if the direct and indirect effect of variables on the outcome is of interest.

For instance, the direct effect of $\eta_{1}$ on $\eta_{2}$ is estimated by $\beta_{21}$, and the indirect effect of $\zeta_{1}$ on $\eta_{2}$ is estimated by $\gamma_{11}$. Alternatively, one could model the direct effect of $\zeta_{1}$ on $\eta_{2}$ with the model depicted in Figure 3, with corresponding coefficient $\gamma_{12}$.

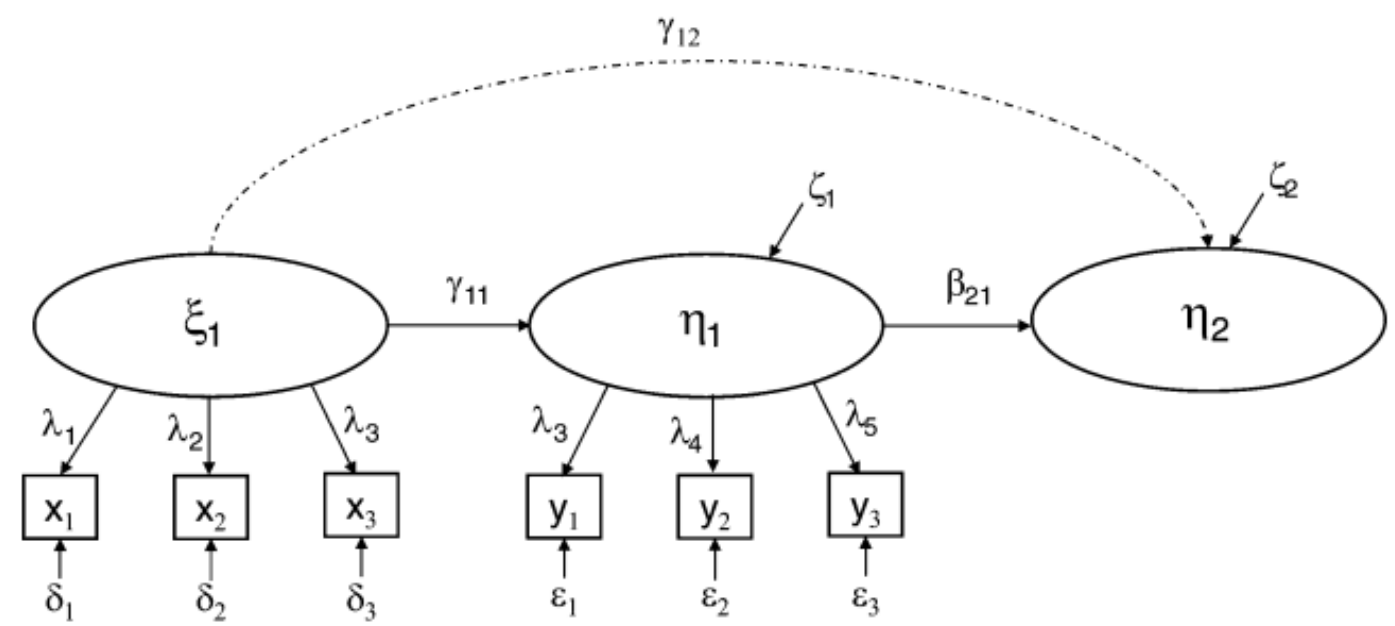

Figure 3: Illustration of SEM diagram, showing the addition of a direct effect in the model Source: Catherine, Nathan, and Nora [36]

These models are estimated using the variance-covariance matrix of the data. Usually, maximum likelihood estimation fitting functions are used to fit the system of equations to the data, but this

method requires that the data be normally distributed and the observations be independent. Variations that relax the assumption of multivariate normality have been developed, including the robust weighted least squares estimator (WLSMV), which allows for binary and categorical dependent variables [40]. To assess the overall model fit, there are a number of fit statistics, including the root mean squared error (RMSEA) and comparative fit index (CFI) [35], and for categorical data, the weighted root mean square residual (WRMR) is appropriate [41]. Hu and Bentler [42] categorize these fit statistics as "comparative" or "absolute." One could also compare nested models, as is done with traditional regression 
models and segregation analysis models, using a likelihood ratio test (LRT) and non-nested models using Akaike's AIC; by contrast, the aforementioned fit statistics (RMSEA, CFI, WRMR, etc.) do not require the models being compared to be nested.

Fursova [43] stated that researchers typically integrate the smart-PLS-SEM technique for developing theory in investigative research. The main applications of smart-PLS-SEM are path analysis, confirmatory factor analysis, regression models, covariance structure models, second-order factor analysis and correlation models as revealed by Hall, Müller, and Saarinen [44]. The approach of structural equation modelling (SEM) enhances the analysis of linear relationship between the manifest variables and latent constructs.

The Partial Least Squares (PLS-SEM) method is a multivariate statistical technique for evaluating a measurement model concurrently such as, the relationship between the four constructs in this study and its indicators with a structural model to point out the relationship between the constructs; this is evidenced in the study of Hair and Hult [28]. In addition to the relationship, it could also manifest obtainable parameter estimates to determine the relationship between unobserved variables.

Typically, the SEM technique gives way for numerous associations to test and compute at once in the single proposed models with several associations instead of examining each connection individually. This present study will adopt the partial least squares (PLS-SEM) technique to scrutinize and analyze the collected data, as it will enhance the evaluation of the conceptual model empirically. According to Vinzi, Chin, Henseler and Wang [45]; Astrachan, Patel and Wanzenried [46], PLS-SEM is a path for the statistical modelling technique, and a complex multivariate analysis for examining the relationships between latent variables.

In the same vein, the PLS-SEM research approach is a flexible, superior and a robust technique to design or build a plausible statistical model [47]; Lowry and Gaskin, [48]; and the PLS-SEM features enhances the achievement of the stated objective. Peterson and Kim [49]; Astrachan, Patel and Wanzenried [46] made emphasis that reliable and valid confirmatory factor analysis can be properly achieved with the use of PLS-SEM path modelling.

PLS-SEM is a statistical tool that has been adopted in different fields including engineering and technology, social sciences, [47]. The technique is well applicable for analysis that 
deals with non-normal data because of its assumed flexibility when concerned with the distribution and normality of variables [48]. According to Lowry and Gaskin [48], the PLS-SEM method enhances the test of complex models that have multi-stage effects, for example, mediating role and other complex models' variables relationships. In line with the various evidences rooted in the body of scientific literature, this study will adopt the partial-least-squares (PLS-SEM) technique for testing and examining the designed conceptual model and achieving the hypothetical statements.

By so doing, it will examine the relationship between the constructs of dynamic capacities and enterprise performance, and the conforming constructs' indicators with a structural model. This study will incorporate the PLS-SEM for data screening, analysis and the underline assumptions will be taken critically in order to compute loadings, path coefficients and weights, the study will also employ the bootstrapping method to determine the significance levels as evidenced in the study of Hair, Hult, Ringle and Sarstedt [28].

Reasons for adopting PLS-SEM are:

i. $\quad$ PLS can be applied to both small and large samples;

ii. It can be adopted in the situation whereby there is no theory or theoretical basis;

iii. It is applicable for both probability and non-probability sampling distribution;

iv. It allows for both reflective and formative latent variables;

v. It requires only the formation of indices or indicators;

The approach will be based on creating latent factors from the questionnaire based on an exploratory factor analysis. The resulting factors will then be evaluated in terms of their influence on the dependent variables in the model setup. There are four sets of equations to be included in the entire model, they are;

i. Measurement of equations: Equation 1 links the measurement indicators (survey items) to the latent factors;

ii. PLS equations: Equation 2 associates the latent factors with individuals' background characteristics;

iii. Structural equations: Equation3 relates the explanatory and the mediator variables; and

iv. Structural equations: Equation 4 links the mediators to the dependent variables.

$I_{r n}=Z^{*}{ }_{l n} \alpha r+v_{r n}$ and $v_{n} \sim N\left(0, \Sigma_{v}\right)$ for $r=1, \ldots, R \ldots \ldots \ldots$ Equation 1 
$Z^{*}{ }_{l n}=S_{l n} \beta_{l}+\omega_{l n}$ and $\omega_{n} \sim N\left(0, \Sigma_{\omega}\right)$ for $l=1, \ldots, L \ldots \ldots \ldots$. Equation 2

$Z^{*} l=Z_{i} \beta_{i}+\varphi_{l}$ and $\varphi_{l} \sim N\left(0, \Sigma_{\varphi}\right)$ for $l=1, \ldots, L, i=1, \ldots, K \quad \ldots \ldots \ldots \ldots$ Equation 3

$Y_{\text {in }}=Z^{*}{ }_{l n} \beta_{z}+\xi_{\text {in }}$ and $\xi_{n} \sim N\left(0, \Sigma_{\xi}\right)$ for $i=1, \ldots, I$

Equation 4

where $I_{r n}$ is the value of an indicator $r$ of the latent construct $Z^{*}{ }_{l n}$ will be perceived by respondent $n, Z^{*}{ }_{l n}$ will be the value of latent construct $l$ for respondent $n, S_{l n}$ will be the vector of $M$ respondents' observed individual characteristics, and $Y_{i n}$ will be the vector of enterprise performance levels. Error terms will be presented as elements $\omega_{l n}, v_{r n}, \xi_{\text {in }}$ of the vectors following a normal distribution with respective covariance matrix $\Sigma_{\omega}, \Sigma_{v}, \Sigma_{\xi}$, while parameters to be estimated are $\alpha_{r}, \beta_{l}, \beta_{i}$, and $\beta_{z}$. Considering $R$ indicators translates into writing $R$ measurement equations and estimating an $(R \times 1)$ vector $\alpha$ of parameters (i.e., one parameter is estimated for each equation), while considering $L$ latent constructs translates into writing $L$ structural equations and estimating an $(M \times L)$ matrix of $\beta$ parameters (i.e., $M$ parameters will be estimated for each equation).

\section{DATA ANALYSIS AND RESULTS}

The first section of result is the descriptive results of all the four constructs. When observing

the mean values, it was shown that they are closer to the upper range (4). Therefore, it can be concluded that food and beverage enterprises in Lagos, Nigeria were able to achieve product innovative activities, and enterprise survival activities. Furthermore, these innovative activities are positively and strongly related with the competitive advantage and competitive intensity. This is shown in Table 1, Table 2, Table 3, and Table 4.

The Table 1 depicts the respondents' perception on innovation product capacity on the five point scales of very high, high, not sure, low and very low. By merging the respondents' responses under very high and high, four hundred and twenty two (422) respondents representing 78.3 percent acknowledged flexibility practices in organization. Four hundred and fourteen (414) respondents representing 76.8 percent acknowledged re-engineering processes in the organization. Three hundred and ninety three (393) respondents representing 72.9 percent acknowledged that solutions centred investments are essential in the organization. Four hundred and thirty (430) respondents representing 81.7 percent 
acknowledged innovation process towards customer needs. Three hundred and eighty three (383) respondents representing 71.0 percent acknowledged that product innovation and measurement level is a product innovation capacity. Four hundred and twenty nine (429) respondents representing 79.6 percent acknowledged that technological and product innovation process as a product innovation capacity.

Table 2 depicts the respondents' perception on enterprise survival capacity on the five point scales of very high, high, not sure, low and very low. By merging the respondents' responses under very high and high, four hundred and thirty seven (437) representing 81.08 percent acknowledged the magnitude of enterprise's superior performance over its competitors. Three hundred and sixty (360) representing 66.79 percent acknowledged the rapid increase in the profitability rate of the organization over the years. Four hundred and twenty six (426) representing 79.03 percent acknowledged the level of profit margin increase of the enterprise over the years.

Four hundred and thirty four (434) representing 80.52 percent acknowledged the rate at which enterprise react more strongly to strategically similar rivals than to small players. Four hundred and twenty one (421) representing 78.11 percent acknowledged the goodwill enterprise has established among the customers. Four hundred and five (405) representing 75.14 percent acknowledged the level of opportunity available to enterprise. Three hundred and seventy (370) representing 68.65 percent acknowledged the extent of enterprise strength when compared to the competitors. Four hundred and thirty eight (438) representing 81.26 percent acknowledged the availability of enterprise products to the market. Four hundred and twenty seven (427) representing 79.22 percent acknowledged the prompt response to defects pointed out by employees. Four hundred and thirty one (431) representing 79.96 percent acknowledged the rate at which enterprise favourably react to external environment.

Table 3 depicts the respondents' perception on the competitive advantage capacity on the five point scales of very high, high, not sure, low and very low. From the merging of respondents' responses under very high and high, it was revealed that four hundred and fourteen (414) respondents representing 76.81 percent agreed to the extent to which customer satisfaction has exceeded that of the competitors. Three hundred and ninety eight (398) respondents representing 73.84 percent acknowledged the degrees to the extent Rate 
at which repeat business of enterprise has exceeded that of the competitors. Three hundred and sixty three (363) respondents representing 67.35 percent agreed to the rate at which service quality has exceeded that of the competitors. Four hundred and forty (440) respondents representing 81.63 percent acknowledged that the enterprise's location attracted competitive advantage.

Also, three hundred and forty eight (348) respondents representing 64.56 percent of the extent to which our enterprise offers highly reliable products to its customers. Four hundred and twenty two (422) respondents representing 78.29 percent acknowledged the rate at which customers' orders are promptly delivered on time. Four hundred and twenty six (426) respondents representing 79.04 percent acknowledged that enterprise's brand has competitive advantage over rivals. Four hundred and thirteen (413) respondents representing 76.62 percent acknowledged the cost of enterprise products compared to the competitors. Three hundred and ninety five (395) respondents representing 73.28 percent acknowledged the rate at which enterprise product quality has exceed that of the competitors. Three hundred and sixty four (364) respondents representing 67.53 percent acknowledged the provision of dependable delivery by the enterprise. Four hundred and thirty four (434) respondents representing 80.52 percent acknowledged the rate at which enterprise is always first in the market to introduce new products. Four hundred and twenty four (424) respondents representing 78.66 percent acknowledged the rate at which enterprise provides customized products. Four hundred and twenty seven (427) respondents representing 79.22 percent acknowledged the extent to which enterprise offers high quality products and services to its customers.

Table 4 depicts the respondents' perception on the competitive intensity of enterprise on the five point scales of very high, high, not sure, low and very low. From the merging of respondents' responses under very high and high, it was revealed that three hundred and seventy (370) respondents representing 68.65 percent acknowledged the high magnitude of 'promotion wars' in the industry. Four hundred and forty (440) respondents representing 81.63 percent acknowledged the high level of competition in the industry. Three hundred and fifty four (354) respondents representing 65.68 percent recognized the high extent to which enterprise competitors' presence in the industry affect customers' patronage. Four hundred and twenty five (425) respondents representing 78.85 percent acknowledged the 
high prevalent price competition in the industry. Four hundred and seventeen (417) respondents representing 77.37 percent recognized the high frequent competitive moves in the industry.

In addition, four hundred and thirty three (433) respondents representing 80.34 percent recognized the degree at which the enterprise constantly seek to know rivals' moves, analysis and track them for competitive actions and responses. Four hundred and four (404) respondents representing 74.95 percent acknowledged the rate at which enterprise's product range is more attractive to consumers than that of the competitors. Three hundred and sixty nine (369) respondents representing 68.46 percent recognized the extent to which enterprises annex opportunities in the external environment. Four hundred and thirty five (435) respondents representing 80.7 percent recognized the rate at which organization tend to produce its products at a low cost. Three hundred and fifty four (354) respondents representing 65.68 percent acknowledged the degree to which one competitor's product matches each other's product offers in the market.

The second section is the findings of SEM as presented in Table 5. Based on SEM techniques, the unitary model is set up to examine the nexus between product innovation and enterprise survival variables. Firstly, there was a positive and insignificant outcome $(0.002 ; \mathrm{t}=0.203, \mathrm{p}>0.05)$. Afterwards, the first-order and second-order combined structural models were identified to

establish the hypotheses on the impacts of competitive intensity and competitive advantage on product innovation, and of their impact on enterprise survival. In this model, the result was $\chi^{2}(85)=389.19(\mathrm{p}<0.05)$ with normed chi-square $\left(\chi^{2} / \mathrm{gl}\right)$ of 4.9 . Though this value is greater than the maximum recommended of 2 and the $\chi^{2}$ is not significant. In view of this, lesson will be drawn from the study of Martínez- López et al. [50] which explain that the insignificant may be as a result of the fact that the samples is larger than 200 as evidenced in this research, which implies the absence of multivariate normality that seems to increase the chi-square statistic. Consequently, there was recommendation that other indicators of goodness should be adopted. Hence, the following were obtained. $\mathrm{CFI}=0.82$, IFI $=0.82$, $\mathrm{NNFI}=0.78$, and RMSEA $=0.08$ (which is between 0.07 and 0.09 ), and the results give an acceptable model. 
Secondly, concerning the first-order model, there is a positive and significant nexus between

competitive intensity and product innovation $(0.39 ; \mathrm{t}=5.69, \mathrm{p}<0.05)$, which validate the first hypothesis.

Thirdly, concerning the second first-order model, there is a negative and insignificant nexus between competitive advantage and product innovation $(-0.035 ; \mathrm{t}=-1.583, \mathrm{p}>.05)$, which invalidate the second hypothesis.

Fourth, concerning the second-order model, there is a positive and insignificant nexus between product innovation and enterprise survival $(0.003 ; \mathrm{t}=0.208, \mathrm{p}>0.05)$ which invalidate the fourth hypothesis. Hence, there was no significant increment in the nexus pertaining product innovation on enterprise survival between the singular and second-order models (from 0.002 to 0.003 ). Hence, the third hypothesis is not supported. 
Table 1. Descriptive analysis of Product innovation

\begin{tabular}{|l|l|l|l|l|l|l|l|}
\hline Variables & IPC1 & IPC2 & IPC3 & IPC4 & IPC5 & IPC6 & $\begin{array}{l}\text { Overall } \\
\text { Mean }\end{array}$ \\
\hline Rating & $\begin{array}{l}\text { Frequency } \\
\text { (Percent) }\end{array}$ & $\begin{array}{l}\text { Frequency } \\
(\text { Percent })\end{array}$ & $\begin{array}{l}\text { Frequency } \\
\text { (Percent) }\end{array}$ & $\begin{array}{l}\text { Frequency } \\
\text { (Percent) }\end{array}$ & $\begin{array}{l}\text { Frequency } \\
\text { (Percent) }\end{array}$ & $\begin{array}{l}\text { Frequency } \\
\text { (Percent) }\end{array}$ & \\
\hline Very Low & $20(3.7)$ & $35(6.5)$ & $25(4.6)$ & $24(4.5)$ & $35(6.5)$ & $24(4.5)$ & \\
\hline Low & $19(3.5)$ & $26(4.8)$ & $48(8.9)$ & $27(5.0)$ & $48(8.9)$ & $30(5.6)$ & \\
\hline Not Sure & $78(14.5)$ & $64(11.9)$ & $73(13.5)$ & $48(8.9)$ & $73(13.5)$ & $56(10.4)$ & \\
\hline High & $288(53.4)$ & $280(51.9)$ & $263(48.8)$ & $292(54.2)$ & $261(48.4)$ & $282(52.3)$ & \\
\hline Very High & $134(24.9)$ & $134(24.9)$ & $130(24.1)$ & $148(27.5)$ & $122(22.6)$ & $147(27.3)$ & \\
\hline Total & $\mathbf{5 3 9 ( 1 0 0 )}$ & $\mathbf{5 3 9 ( 1 0 0 )}$ & $\mathbf{5 3 9 ( 1 0 0 )}$ & $\mathbf{5 3 9 ( 1 0 0 )}$ & $\mathbf{5 3 9}(\mathbf{1 0 0})$ & $\mathbf{5 3 9}(\mathbf{1 0 0})$ & \\
\hline Mean & 3.92 & 3.84 & 3.79 & 3.95 & 3.72 & 3.92 & $\mathbf{3 . 8 6}$ \\
\hline $\begin{array}{l}\text { Std. } \\
\text { Deviation }\end{array}$ & 0.93 & 1.06 & 1.05 & 0.98 & 1.11 & 0.99 & $\mathbf{1 . 0 2}$ \\
\hline
\end{tabular}

Table 2. Descriptive analysis of Enterprise survival

\begin{tabular}{|c|c|c|c|c|c|c|c|c|c|c|}
\hline Variables & ESC1 & ESC2 & ESC3 & ESC4 & ESC5 & ESC6 & ESC7 & ESC8 & ESC9 & ESC10 \\
\hline Ratings & $\begin{array}{l}\text { Frequency } \\
\text { (Percent) }\end{array}$ & $\begin{array}{l}\text { Frequency } \\
\text { (Percent) }\end{array}$ & $\begin{array}{l}\text { Frequency } \\
\text { (Percent) }\end{array}$ & $\begin{array}{l}\text { Frequency } \\
\text { (Percent) }\end{array}$ & $\begin{array}{l}\text { Frequency } \\
\text { (Percent) }\end{array}$ & $\begin{array}{l}\text { Frequency } \\
\text { (Percent) }\end{array}$ & $\begin{array}{l}\text { Frequency } \\
\text { (Percent) }\end{array}$ & $\begin{array}{l}\text { Frequency } \\
\text { (Percent) }\end{array}$ & $\begin{array}{l}\text { Frequency } \\
\text { (Percent) }\end{array}$ & $\begin{array}{l}\text { Frequency } \\
\text { (Percent) }\end{array}$ \\
\hline Very Low & $19(3.53)$ & $35(6.49)$ & $20(3.71)$ & $19(3.53)$ & $17(3.15)$ & $36(6.68)$ & $18(3.34)$ & $18(3.34)$ & $19(3.53)$ & $18(3.34)$ \\
\hline Low & $20(3.71)$ & $51(9.46)$ & $27(5.01)$ & $22(4.08)$ & $19(3.53)$ & $19(3.53)$ & $53(9.83)$ & $21(3.90)$ & $28(5.20)$ & $22(4.08)$ \\
\hline Not Sure & 63 (11.69) & $93(17.25)$ & $66(12.24)$ & $64(11.87)$ & $82(15.21)$ & 79 (14.66) & $98(18.18)$ & $62(11.50)$ & $65(12.06)$ & $68(12.62)$ \\
\hline High & $\begin{array}{l}291 \\
(53.99)\end{array}$ & $251(46.57)$ & $281(52.13)$ & $\begin{array}{l}294 \\
(54.55)\end{array}$ & $\begin{array}{l}288 \\
(53.43)\end{array}$ & $\begin{array}{l}279 \\
(51.76)\end{array}$ & $253(46.94)$ & $292(54.17)$ & $\begin{array}{l}282 \\
(52.32)\end{array}$ & $292(54.17)$ \\
\hline
\end{tabular}




\begin{tabular}{|l|l|l|l|l|l|l|l|l|l|}
\hline Very High & $\begin{array}{l}146 \\
(27.09)\end{array}$ & $109(20.22)$ & $145(26.90)$ & $\begin{array}{l}140 \\
(25.97)\end{array}$ & $\begin{array}{l}133 \\
(24.68)\end{array}$ & $\begin{array}{l}126 \\
(23.38)\end{array}$ & $117(21.71)$ & $146(27.09)$ & $\begin{array}{l}145 \\
(26.90)\end{array}$ \\
\hline Mean & 3.97 & 3.65 & 3.94 & 3.958 & 3.93 & 3.82 & 3.74 & 3.98 & 3.94 \\
\hline $\begin{array}{l}\text { Std. } \\
\text { Deviation }\end{array}$ & 0.92 & 1.10 & 0.96 & 0.93 & 0.91 & 1.04 & 1.01 & 0.92 & 0.96 \\
\hline
\end{tabular}

Table 3. Competitive advantage

\begin{tabular}{|c|c|c|c|c|c|c|c|c|c|c|c|c|c|}
\hline Variables & CA1 & CA2 & CA3 & CA4 & CA5 & CA6 & CA7 & CA8 & CA9 & CA10 & CA11 & CA12 & CA13 \\
\hline Rating & $\begin{array}{l}\text { Frequency } \\
\text { (Percent) }\end{array}$ & $\begin{array}{l}\text { Frequency } \\
\text { (Percent) }\end{array}$ & $\begin{array}{l}\text { Frequency } \\
\text { (Percent) }\end{array}$ & $\begin{array}{l}\text { Frequency } \\
\text { (Percent) }\end{array}$ & $\begin{array}{l}\text { Frequency } \\
\text { (Percent) }\end{array}$ & $\begin{array}{l}\text { Frequency } \\
\text { (Percent) }\end{array}$ & $\begin{array}{l}\text { Frequency } \\
\text { (Percent) }\end{array}$ & $\begin{array}{l}\text { Frequency } \\
\text { (Percent) }\end{array}$ & $\begin{array}{l}\text { Frequency } \\
\text { (Percent) }\end{array}$ & $\begin{array}{l}\text { Frequency } \\
\text { (Percent) }\end{array}$ & $\begin{array}{l}\text { Frequency } \\
\text { (Percent) }\end{array}$ & $\begin{array}{l}\text { Frequency } \\
\text { (Percent) }\end{array}$ & $\begin{array}{l}\text { Frequency } \\
\text { (Percent) }\end{array}$ \\
\hline $\begin{array}{l}\text { Very } \\
\text { Low }\end{array}$ & $21(3.90)$ & $40(7.42)$ & $17(3.16)$ & $18(3.34)$ & $36(6.68)$ & $18(3.34)$ & $20(3.71)$ & $20(3.31)$ & $36(6.68)$ & $17(3.15)$ & $18(3.34)$ & $18(3.34)$ & $18(3.34)$ \\
\hline Low & $22(4.08)$ & $22(4.08)$ & $55(10.20)$ & $20(3.71)$ & $57(10.58)$ & $29(5.38)$ & $27(5.01)$ & $24(4.45)$ & $21(3.90)$ & $56(10.39)$ & $21(3.90)$ & $29(5.38)$ & $25(4.64)$ \\
\hline Not Sure & $82(15.21)$ & 79 (14.66) & $\begin{array}{l}104 \\
(19.30)\end{array}$ & $61(11.32)$ & $98(18.18)$ & $70(12.99)$ & $66(12.25)$ & $82(15.21)$ & $87(16.14)$ & $\begin{array}{l}102 \\
(18.92)\end{array}$ & $66(12.25)$ & $68(12.62)$ & $69(12.80)$ \\
\hline High & $\begin{array}{l}283 \\
(52.51) \\
\end{array}$ & $274(50.83)$ & $\begin{array}{l}248 \\
(46.01) \\
\end{array}$ & $\begin{array}{l}291 \\
(53.99) \\
\end{array}$ & $\begin{array}{l}244 \\
(45.27) \\
\end{array}$ & $\begin{array}{l}277 \\
(51.39) \\
\end{array}$ & $\begin{array}{l}289 \\
(53.62) \\
\end{array}$ & $\begin{array}{l}282 \\
(52.32) \\
\end{array}$ & $\begin{array}{l}271 \\
(50.28) \\
\end{array}$ & $\begin{array}{l}248 \\
(46.01) \\
\end{array}$ & $\begin{array}{l}291 \\
(53.99) \\
\end{array}$ & $\begin{array}{l}280 \\
(51.95) \\
\end{array}$ & $289(53.62)$ \\
\hline $\begin{array}{l}\text { Very } \\
\text { High }\end{array}$ & $\begin{array}{l}131 \\
(24.30)\end{array}$ & $124(23.01)$ & $\begin{array}{l}115 \\
(21.34)\end{array}$ & $\begin{array}{l}149 \\
(27.64)\end{array}$ & $\begin{array}{l}104 \\
(19.29)\end{array}$ & $\begin{array}{l}145 \\
(26.90)\end{array}$ & $\begin{array}{l}137 \\
(25.42)\end{array}$ & $\begin{array}{l}131 \\
(24.30)\end{array}$ & $\begin{array}{l}124 \\
(23.01)\end{array}$ & $\begin{array}{l}116 \\
(21.52)\end{array}$ & $\begin{array}{l}143 \\
(26.53)\end{array}$ & $\begin{array}{l}144 \\
(26.72)\end{array}$ & $138(25.60)$ \\
\hline Mean & 3.89 & 3.78 & 3.72 & 3.99 & 3.6 & 3.93 & 3.92 & 3.89 & 3.79 & 3.72 & 3.97 & 3.93 & 3.94 \\
\hline $\begin{array}{l}\text { Std. } \\
\text { Deviation }\end{array}$ & 0.95 & 1.08 & 1.01 & 0.92 & 1.11 & 0.96 & 0.95 & 0.95 & 1.05 & 1.02 & 0.92 & 0.95 & 0.93 \\
\hline
\end{tabular}

Table 4. Competitive intensity

\begin{tabular}{|l|l|l|l|l|l|l|l|l|l|l|}
\hline Variables & CA1 & CA2 & CA3 & CA4 & CA5 & CA6 & CA7 & CA8 & CA9 & CA10 \\
\hline Rating & $\begin{array}{l}\text { Frequency } \\
\text { (Percent) }\end{array}$ & $\begin{array}{l}\text { Frequency } \\
\text { (Percent) }\end{array}$ & $\begin{array}{l}\text { Frequency } \\
\text { (Percent) }\end{array}$ & $\begin{array}{l}\text { Frequency } \\
\text { (Percent) }\end{array}$ & $\begin{array}{l}\text { Frequency } \\
\text { (Percent) }\end{array}$ & $\begin{array}{l}\text { Frequency } \\
\text { (Percent) }\end{array}$ & $\begin{array}{l}\text { Frequency } \\
\text { (Percent) }\end{array}$ & $\begin{array}{l}\text { Frequency } \\
\text { (Percent) }\end{array}$ & $\begin{array}{l}\text { Frequency } \\
\text { (Percent) }\end{array}$ & $\begin{array}{l}\text { Frequency } \\
\text { (Percent) }\end{array}$ \\
\hline $\begin{array}{l}\text { Very } \\
\text { Low }\end{array}$ & $17(3.15)$ & $18(3.34)$ & $38(7.05)$ & $18(3.34)$ & $17(3.15)$ & $18(3.34)$ & $36(6.68)$ & $17(3.15)$ & $19(3.53)$ & $35(6.5)$ \\
\hline Low & $53(9.83)$ & $19(3.54)$ & $53(9.83)$ & $29(5.38)$ & $22(4.08)$ & $22(4.08)$ & $20(3.71)$ & $53(9.83)$ & $21(3.9)$ & $54(10.02)$ \\
\hline Not Sure & $99(18.37)$ & $62(11.5)$ & $94(17.44)$ & $67(12.43)$ & $83(15.4)$ & $66(12.24)$ & $79(14.66)$ & $100(18.55)$ & $64(11.9)$ & $96(17.81)$ \\
\hline
\end{tabular}




\begin{tabular}{|c|c|c|c|c|c|c|c|c|c|c|}
\hline High & $\begin{array}{l}253 \\
(46.94)\end{array}$ & $\begin{array}{l}295 \\
(54.73)\end{array}$ & $248(46.01)$ & $\begin{array}{l}280 \\
(51.95)\end{array}$ & $285(52.88)$ & $\begin{array}{l}294 \\
(54.55)\end{array}$ & $\begin{array}{l}277 \\
(51.39)\end{array}$ & $253(46.94)$ & $290(53.8)$ & $248(46.01)$ \\
\hline $\begin{array}{l}\text { Very } \\
\text { High }\end{array}$ & $\begin{array}{l}117 \\
(21.71)\end{array}$ & $145(26.9)$ & $106(19.67)$ & $145(26.9)$ & $132(24.49)$ & $\begin{array}{l}139 \\
(25.79)\end{array}$ & $\begin{array}{l}127 \\
(23.56)\end{array}$ & $116(21.52)$ & $145(26.9)$ & $106(19.67)$ \\
\hline Mean & 3.74 & 3.98 & 3.61 & 3.94 & 3.95 & 3.92 & 3.81 & 3.74 & 3.97 & 3.62 \\
\hline $\begin{array}{l}\text { Std. } \\
\text { Deviation }\end{array}$ & 1.01 & 0.91 & 1.12 & 0.95 & 0.92 & 0.92 & 1.05 & 1.01 & 0.93 & 1.11 \\
\hline
\end{tabular}


Table 5. Path analysis

\begin{tabular}{|c|c|c|c|c|}
\hline Path & Direct effect & t-value & Hypothesis & Supported \\
\hline $\begin{array}{l}\text { Singular model } \\
\text { a. Product innovation } \longrightarrow \text { Enterprise survival }\end{array}$ & 0.002 & $0.203^{*}$ & & \\
\hline $\begin{array}{l}\text { First-order model } \\
\text { b. Competitive intensity } \longrightarrow \text { Product innovation } \\
\text { c. Competitive advantage } \longrightarrow \text { Product innovation }\end{array}$ & $\begin{array}{l}0.39 \\
-0.035 \\
\end{array}$ & $\begin{array}{l}5.69 * \\
-1.583 * \\
\end{array}$ & $\begin{array}{l}\mathrm{H}_{1} \\
\mathrm{H}_{2} \\
\end{array}$ & $\begin{array}{l}\text { Valid } \\
\text { Invalid }\end{array}$ \\
\hline $\begin{array}{l}\text { Second-order model } \\
\text { d. Product innovation } \longrightarrow \text { Enterprise survival }\end{array}$ & 0.003 & $0.208^{*}$ & $\mathrm{H}_{3}$ & Invalid \\
\hline
\end{tabular}

$* p<.05$

$\chi^{2}=\mathrm{CFI}=0.82, \mathrm{IFI}=0.82, \mathrm{NNFI}=0.78$, and $\mathrm{RMSEA}=0.08$

\section{DISCUSSION OF FINDINGS}

Regarding the food and beverage enterprises in Lagos, Nigeria, this study discovered that competitive intensity has huge positive implication on product innovation at $(0.39 ; \mathrm{t}=5.69, \mathrm{p}<$ 0.05). This gives numerical evidence that, in the face of more market competition, enterprises will be pressured to adopt the model of costs reduction on products which will enhance the reduction of product prices, and will have significant impact on profit. This corroborates the findings of Miller and Friesen [51]; Auh and Menguc [53]; Chang et al. [11]; Abebe and Angriawan [54] which finds that enterprises adopts product innovation such that they improvement product development in the face of high competition. However, the findings reveal that there is no significance between competitive advantage and product innovation at $(0.002 ; t=0.203, p>0.05)$, and there is no significance between product innovation and enterprise survival at $(-0.035 ; \mathrm{t}=-$ $1.583, \mathrm{p}>.05)$.

In summary, the major finding of the study is that there is a nexus between competitive intensity and product innovation, and the nexus is affected by other antecedent variables in the food and beverage enterprises in Lagos, Nigeria. As a result, the food and beverage enterprises should concentrate more on product innovation so that they will be able to stand the intensity of competition.

\section{CONCLUSION}

Product innovation is a crucial factor in enterprise survival. Even though there are sources from strategic theory that guides the clear comprehension towards appreciating the nexus between these 
two variables (product innovation and enterprise survival), there are still many lacunas that should be addressed and filled. Consequently, the need for additional empirical corroboration or support is pertinent. This study aimed at verifying the nexus between product innovation and enterprise survival, and how they are affected by the existence of antecedent variables such as competitive intensity and competitive advantage.

In the methodology, this study adopts the conduct of explanatory and cross-sectional investigations through the use of structural equation modelling (SEM) to a sample of selected food and beverages enterprises in Lagos, Nigeria. Regarding the food and beverage enterprises in Lagos, Nigeria, this study discovered that competitive intensity has huge positive implication on product innovation at $(0.39 ; \mathrm{t}=5.69, \mathrm{p}<0.05)$. This gives numerical evidence that, in the face of more market competition, enterprises will be pressured to adopt the model of costs reduction on products which will enhance the reduction of product prices, and will have significant impact on profit. However, the findings reveal that there is no significance between competitive advantage and product innovation at $(0.002 ; \mathrm{t}=0.203, \mathrm{p}>0.05)$, and there is no significance between product innovation and enterprise survival at $(-0.035 ; \mathrm{t}=-1.583, \mathrm{p}>.05)$.

As a result, the food and beverage enterprises should concentrate more on product innovation so that they will be able to stand the intensity of competition. The results emanated from the study is germane as it make significant contribution to literature and the body of knowledge and on strategic management by enlightening that competitive intensity is a necessary inducement for product innovation.

Finally, since the study is limited to four variables and six food and beverage enterprises across Lagos, Nigeria, future studies may consider exogenous variables and sample drawn from enterprises across south-western states.

Author Contributions: Conceptualization, J.O.A., Z.X.J. and T.K.A.D.; Data curation, L.L.Z., and J.O.A., J.P.M., A.E.O., and T.K.A.D; Formal analysis, L.L.Z., J.O.A., A.E.O. and T.K.A.D.; Funding acquisition, L.L.Z. and Z.X.J.; Investigation, J.O.A., J.P.M and T.K.A.D.; Methodology, J.O.A., J.P.M, A.E.O. and Z.X.J.; Project administration, L.L.Z. and Z.X.J.; Resources, L.L.Z., J.P.M and A.E.O.; Software, J.O.A. and A.E.O.; Supervision, L.L.Z.; Writing - original draft, J.O.A. and A.E.O.; Writing review \& editing, L.L.Z., J.O.A., J.P.M and Z.X.J.All authors have read and agreed to the published version of the manuscript. 
Funding: This empirical work was supported the National Natural Science Foundation of China (NSFC), '71804061',.

Conflicts of Interest: The authors declare no conflict of interest.

Acknowledgments: We would like to thank the Overseas Educational College of Jiangsu University for all research project supervisory supports rendered throughout the entire research's development and completion.

\section{References}

1. Rosenbusch, N., Brinckmann, J., and Bausch, A. (2011). Is innovation always beneficial? A meta-analysis of the relationship between innovation and performance in SMEs. Journal of Business Venturing, 26(4), 441-457. doi:10.1016/j.jbusvent.2009.12.002

2. Marín-Idárraga, D. A., Hurtado González, J. M., and Cabello Medina, C. (2016). The antecedents of exploitation-exploration and their relationship with innovation: A study of managers' cognitive maps. Creativity and Innovation Management, 25(1), 18-37. doi:10.1111/caim.12139

3. Keupp, M. M., Palmié, M., and Gassmann, O. (2012). The strategic management of innovation: A systematic review and paths for future research. International Journal of Management Reviews, 14(4), 367- 390. doi:10.1111/j.1468-2370.2011.00321.x

4. Damanpour, F. (1987). The adoption of technological, administrative, and ancillary innovations: Impact of organizational factors. Journal of Management, 13(4), 675-688. doi:10.1177/014920638701300

5. Stock, R., and Zacharias, N. (2011). Patterns and performance outcomes of innovation orientation. Journal of the Academy of Marketing Science, 39(6), 870-888. doi:10.1007/s11747-010-0225-2

6. Marín-Idárraga, D. A., and Cuartas-Marín, J. C. (2013). Structural coalignment influence on SMEs performance. International Journal of Business and Management, 8(22), 76-91. doi:10.5539/ijbm.v8n22p76

7. Alegre, J., and Chiva, R. (2013). Linking entrepreneurial orientation and firm performance: The role of organizational learning capability and innovation performance. Journal of Small Business Management, 51(4), 491-507. doi:10.1111/jsbm.12005

8. Heunks, F. J. (1998). Innovation, creativity and success. Small Business Economics, 10(3), 263-272. doi:10.1023/A:1007968217565 
9. Freel, M. S., and Robson, P. J. (2004). Small firm innovation, growth and performance: Evidence from Scotland and Northern England. International Small Business Journal, 22(6), 561-575. doi:10.1177/0266242604047410

10. Vermeulen, P. A., De Jong, J. P., and O'shaughnessy, K. (2005). Identifying key determinants for new product introductions and firm performance in small service firms. The Service Industries Journal, 25(5), 625-640. doi:10.1080/02642060500100783

11. Chang, Y., Hughes, M., and Hotho, S. (2011).Internal and external antecedents of SMEs' innovation ambidexterity outcomes. Management Decision, 49(10), 1658-1676. doi:10.1108/00251741111183816

12. Jaworski, B. J., and Kohli, A. K. (1993). Market orientation: Antecedents and consequences. Journal of Marketing, 57(3), 53-70. doi:10.2307/1251854

13. Kim, N., and Atuahene-Gima, K. (2010). Using exploratory and exploitative market learning for new product development. Journal of Product Innovation Management, 27(4), 519-536. doi:10.1111/j.1540-5885.2010.00733.x

14. Adeniran, A. O., and Sidiq, O. B. (2018). Economic recession and the way-out: Nigeria as case study. Global Journal of Humanities and Social Science: E Economics, 18(1), 1-6.

15. Cyert, R. M., and March, J. G. (1992). A behavioral theory of the firm (2 ${ }^{\text {nd }}$ ed.). Oxford, UK: Blackwell Publishing.

16. Lecerf, M. (2012). Internationalization and innovation: The effects of a strategy mix on the economic performance of French SMEs. International Business Research, 5(6), 2-13. doi:10.5539/ibr.v5n6p2

17. Nohria, N., and Gulati, R. (1996). Is slack good or bad for innovation? Academy of Management Journal, 39(5), 1245-1264. doi:10.2307/256998

18. Drucker, P. F. (1985). The discipline of innovation. Harvard Business Review, 63(3), 6772.

19. Wolfe, R. A. (1994). Organizational innovation: Review, critique and suggested research. Journal of Management Studies, 31(3), 405-431. doi:10.1111/j.1467-6486.1994.tb00624.x

20. Damanpour, F. (1996). Bureaucracy and innovation revisited: Effects of contingency factors, industrial sectors, and innovation characteristics. Journal of High Technology Management Research, 7(2), 149-173. doi:10.1016/S1047-8310(96)90002-4 
21. Damanpour, F., and Gopalakrishnan, S. (1999). Organizational adaptation and innovation: The dynamics of adopting innovation types. In K. Brockoff, A. Chakrabarti, and J. Hauschildt (Eds.), The dynamics of innovation: Strategic and managerial implications (pp. 57-80). Berlin, Germany: Springer-Verlag.

22. Damanpour, F., and Wischnevsky, D. J. (2006). Research on innovation in organizations: Distinguishing innovation-generating from innovation-adopting organizations. Journal of Engineering and Technology Management, 23(4), 269-291. doi:10.1016/j. jengtecman.2006.08.

23. Gopalakrishnan, S., Kessler, E. H., and Scillitoe, J. L. (2010). Navigating the innovation landscape: Past research, present practice, and future trends. Organization Management Journal, 7(4), 262-277. doi:10.1057/omj.2010.36

24. Van de Ven, A. H. (1986). Central problems in the management of innovation. Management Science, 32(5), 590-607. doi:10.1287/mnsc.32.5.590

25. Burton, R., and Obel, B. (2004). Strategic organizational diagnosis and design: The dynamics of fit. Norwell, MA: Kluwer Academic Publishers.

26. Ánzola, O., Marín-Idárraga, D. A., and Cuartas, J. C. (2017). Fundamentación teórica de la cultura, la estructura y la estrategia. Referentes para el análisis y diseño organizacional. [Theoretical foundation of culture, structure and strategy. Referents for organizational analysis and design]. Bogotá, Colombia: Universidad Externado de Colombia.

27. Wang, C. (2014). A longitudinal study of innovation competence and quality management on firm performance. Innovation, 16(3), 392- 403. doi:10.1080/14479338.2014.11081995

28. Hair, J. F., Hult, G. T. M., Ringle, C., and Sarstedt, M. (2013). A Primer on Partial Least Squares Structural Equation Modeling (PLS-SEM); SAGE Publications: Thousand Oaks, CA, USA.

29. Ziokowska, M. (2013). Relational resources management as source of company's innovativeness and competitive advantage. Journal of Economic, Business and Management, 2(3), 202-208.

30. Frankfort-Nachmias, C., and Nachmias, D. (2008). Research methods in the social sciences, ( $7^{\text {th }}$ Ed.). New York: Worth Publishers.

31. CBN (2003). Contemporary economic policy issues in Nigeria. Abuja, Nigeria: CBN Publication. 
32. Akpan, P. L., Ikon, Chukwunonyeand Momoh (2016). Economic environment and performance of food and beverages sub-sector of a developing economy: Nigeria. International Journal of Recent Research in Commerce Economics and Management (IJRRCEM), 3 (3), 85-90.

33. Fornell, C., and Larcker, D. F. (1981). Evaluating structural equation models with unobservable variables and measurement error. Journal of Marketing Research, 18(1), 3950. doi:10.2307/3151312

34. Zikmund, W. G. (2003). Exploring Marketing Research, $8^{\text {th }}$ Edition, Thompson Learning/Southwestern, Cincinnati, $\mathrm{OH}$.

35. Bollen, K. (1989). Structural Equations with Latent Variables. John Wiley \& Sons, New York.

36. Catherine, M. S., Nathan, J. M., and Nora, L. N. (2012). Structural Equation Modelling, Chapter 27, Pp. 495-512 in Robert C. Elston et al. (eds.), Statistical Human Genetics: Methods and Protocols, Methods in Molecular Biology, 850, DOI 10.1007/978-1-61779$555-8 \_2$

37. McDonald, R. P., and Ho, M. H. (2002). Principles and Practice in Reporting Structural Equation Analyses. Psychol. Methods, 7: 64-82.

38. Pearl, J. (2000). Causality: Models, Reasoning, and Inference. Cambridge University Press, New York, New York.

39. Bollen, K. (2001). Structural Equations with Latent Variables. John Wiley \& Sons, New York.

40. Malhotra, N. K. (1999). Marketing research: An applied orientation. London: Prentice-Hall International.

41. Hooper, D., Coughlan, J., and Mullen, M. R. (2008). Structural equation modelling: Guidelines for determining model fit. Electronic Journal of Business Research Methods, 6(1), 53-59.

42. Kaplan, R. S., and Norton, D. R. (2005). The balanced scorecard: Measures that drive performance. Harvard Business Review, 83(7), 172-180.

43. Fursova, J. (2016). The Business of Community Development and the Right to the City: Reflections on the Neoliberalization Processes in Urban Community Development. Community Development Journal, 53, 119-135. 
44. Hall, P. C. M., Müller, D. K., and Saarinen, P. J. (2008). Nordic Tourism: Issues and Cases; Channel View Publications: Bristol, UK.

45. Vinzi, V. E., Chin, W. W., Henseler, J., and Wang, H. (2010). Handbook of Partial Least Squares: Concepts, Methods and Applications, $1^{\text {st }}$ ed.; Springer: Berlin/Heidelberg, Germany, pp. 1-798.

46. Astrachan, C. B., Patel, V. K., and Wanzenried, G. (2014). A Comparative Study of CBSEM and PLS-SEM for Theory Development in Family Firm Research. Journal of Family Business Strategy, 5, 116-128.

47. Ringle, C. M., Sinkovics, R. R., and Henseler, J. (2009). The Use of Partial Least Squares Path Modelling in International Marketing. In New Challenges to International Marketing; Emerald Group Publishing Limited: West Yorkshire, UK, Pp. 277-319.

48. Lowry, P. B., and Gaskin, J. (2014). Partial Least Squares (PLS) Structural Equation Modeling (SEM) for Building and Testing Behavioral Causal Theory: When to Choose It and How to Use It. IEEE Transportation Professional Communication, 57, 123-146.

49. Peterson, R.; and Kim, Y. (2013). On the Relationship between Coefficient Alpha and Composite Reliability. Journal of Applied Psychology, 98, 194

50. Neely, A., Gregory, M., and Platts, K. (1995). Performance measurement system design: A literature review and research agenda. International Journal of Operations and Production Management, 15(4), 80-116. doi:10.1108/01443579510083622

51. Miller, D., and Friesen, P. H. (1983). Strategy-making and environment: The third link. Strategic Management Journal, 4(3), 221-235. doi:10.1002/ smj.4250040304

52. Zahra, S. A. (1996). Technology strategy and financial performance: Examining the moderating role of the firm's competitive environment. Journal of Business Venturing, 11(3), 189-219. doi:10.1016/0883-9026(96)00001-8

53. Auh, S., and Menguc, B. (2005). Balancing exploration and exploitation: The moderating role of competitive intensity. Journal of Business Research, 58(12), 1652-1661. doi:10.1016/j.jbusres

54. Abebe, M. A., and Angriawan, A. (2014). Organizational and competitive influences of exploration and exploitation activities in small firms. Journal of Business Research, 67(3), 339-345. doi:10.1016/j. jbusres.2013.01.015 